\title{
Optimization of Condition for Producing Laccase by White Rot Fungus
}

\author{
Zhao Songwen \\ School Of Forestry \\ Northeast Forestry University \\ Harbin 150040, China \\ rafa_songwenzhao@126.com \\ Han Song \\ School Of Forestry \\ Northeast Forestry University \\ Harbin 150040, China \\ rafa_songwenzhao@126.com \\ Ge Wenrui \\ School Of Forestry \\ Northeast Forestry University \\ Harbin 150040, China \\ rafa_songwenzhao@126.com
}

\author{
Zong Xinxuan \\ School Of Forestry \\ Northeast Forestry University \\ Harbin 150040,China \\ rafa_songwenzhao@126.com \\ Tian Yongqiang \\ School Of Forestry \\ Northeast Forestry University \\ Harbin 150040, China \\ rafa_songwenzhao@126.com
}

\begin{abstract}
White rot fungi are essential in forest ecology and are deeply involved in wood decomposition and the biodegradation of various xenobiotics.According to the biodegradation of white rot fungi and the application of Laccase to environmentand industry, the condition of producing Laccase by Pleurotus ostrcatus was studied.Results showed that the optimum culture components were: $10 \mathrm{~g} / \mathrm{L}$ glucose, $5 \mathrm{~g} / \mathrm{L}$ yeast extract, $3 \mathrm{~g} / \mathrm{L}$ $\mathrm{KH}_{2} \mathrm{PO}_{4}, 1.5 \mathrm{~g} / \mathrm{L} \mathrm{MgSO}{ }_{4} \cdot 7 \mathrm{H}_{2} \mathrm{O}, 70 \mathrm{~mL} / \mathrm{L}$ trace elements solution. The optimum $\mathrm{pH}$ of production Laccase was 4.8.
\end{abstract}

\section{Keywords:white rot fungus; laccase}

\section{INTRODUCTION}

White rot fungus is a kind of basidiomycetes, has a strong, degrading lignin peroxidase, manganese peroxidase and laccase, the role in environmental protection is more and more important. At home and abroad for many years, the white rot fungus (Phanerochaete chrysosporium) research is becoming more deeply.Jiang Xiaoyun[1] research such as vaccination white rot fungus (Phanerochaeteorium) compost restoration of soil contaminated with pentachlorophenol, results after 60 days of compost, the degradation of pentachlorophenol rate above $94 \%$, and immobilized cultivation mode is better than that of free training mode, immobilized white rot fungus in $9 \mathrm{~d}$ for the degradation of pentachlorophenol rate reached 50\%. White rot fungus (Phanerochaete chrysosporium) degradation of dye was studied by Molde[2] and his colleagues in a fixed bed bioreactor, measured manganese peroxidase and lignin peroxidase enzymatic activity of $1293 \mathrm{u} / \mathrm{L}$ respectively, $225 \mathrm{u} / \mathrm{L}$, dyestuff dosing 15 min after the degradation rate of $24 \%$. The present study showed that a lot of white-rot fungus (Phanerochaete chrysosporium) for bacterial growth in
North America, haven't found in our country, therefore, in the prevention and control of environmental pollution, the research and development within the territory of China, white-rot fungus has important theoretical significance and extensive application value.

Laccase is a kind of polyphenol oxidase containing copper, in 1883, the Japanese yoshida, for the first time found that laccase from sumac, laccase according to its source can be classified two categories: sumac laccase and fungal laccase. Laccase is widely exist in fungi, especially the white-rot fungus, is an important producing laccase bacteria. Because of laccase could catalyze many aromatic compounds and a wide range of substrates, has great practical application value. In recent years, laccase in papermaking industry, food industry are the important research and application, especially in the area of environmental protection is the research hot spot, such as the degradation of toxic and harmful substances in the environment, dyes decolorizing and miscellaneous Finn oil substances in soil from many aspects, such as the removal of the elimination of environmental pollutants plays a big role.

This experiment give ear to the Pleurotus ostreatus medium and culture environment of laccase production optimization, in order to obtain the strain and the best conditions for producing laccase optimization study the potato liquid medium in middle laccase enzyme activity and the growth condition, better application in environmental pollution control for the future to lay the theoretical foundation and technical support. 


\section{EXPERIMENTAL}

\section{A. Instruments and reagents}

Main reagents:white rot fungus(Pleurotus ostreatus),cellulose reagent peel potatoes (chop)200g, glucose,AGAR, distilled water, trace elements solution,etc.

The main equipment: 752 type visible spectrophotometer,HZQ-X100 oscillation incubator,Water purifying bench operation sterilization,Room large vertical wave bottles of ark.

\section{B. White rot fungus(Pleurotus ostreatus) training}

The growth in incline to trichoderma viride and corning trichoderma activation by incubator $25^{\circ} \mathrm{C}$, after 3 days inoculation in agar-solidified medium containing inclined plate, After 6 days the trichoderma viride and corning trichoderma covered the flat, puncher into $10 \mathrm{~mm}$ diameter with sterile, inoculation of bacteria in the liquid medium containing $100 \mathrm{ml} 250 \mathrm{ml}$ triangle bottle, 3 slices inoculated quantity.

\section{Given the medium}

The solid medium.PDA solid culturate.Potatoes peel (rinsed) $200 \mathrm{~g}$, glucose $20 \mathrm{~g}$, AGAR $15 \mathrm{~g}$, distilled water $1 \mathrm{~L}$, $121^{\circ} \mathrm{C}$, 40min sterilization.

Liquid medium. Wave bottle fermentation (medium).Potatoes peel (rinsed) $200 \mathrm{~g}$, glucose $10 \mathrm{~g}$, yeast extract $5 \mathrm{~g}, \mathrm{KH}_{2} \mathrm{PO}_{4} 3 \mathrm{~g}, \mathrm{MgSO}_{4} \cdot 7 \mathrm{H}_{2} \mathrm{O} 1.5 \mathrm{~g}$, trace elements solution $\left(\mathrm{MgSO}_{4} \cdot 7 \mathrm{H}_{2} \mathrm{O} 3 \mathrm{~g} / \mathrm{L}, \mathrm{MnSO}_{4} \cdot \mathrm{H}_{2} \mathrm{O} 0.5 \mathrm{~g} / \mathrm{L}, \mathrm{NaCl}\right.$ $1 \mathrm{~g} / \mathrm{L}, \mathrm{FeSO}_{4} \cdot 7 \mathrm{H}_{2} \mathrm{O} 0.1 \mathrm{~g} / \mathrm{L}, \mathrm{CoCl}_{2} 0.1 \mathrm{~g} / \mathrm{L}, \mathrm{ZnSO}_{4} \cdot 7 \mathrm{H}_{2} \mathrm{O}$ $0.1 \mathrm{~g} / \mathrm{L}, \mathrm{CuSO}_{4} \cdot 5 \mathrm{H}_{2} \mathrm{O} 0.1 \mathrm{~g} / \mathrm{L}, \mathrm{KAl}\left(\mathrm{SO}_{4}\right)_{2} \cdot 12 \mathrm{H}_{2} \mathrm{O}$ $\left.0.01 \mathrm{~g} / \mathrm{L}, \mathrm{H}_{3} \mathrm{BO}_{3} 0.01 \mathrm{~g} / \mathrm{L}, \mathrm{Na}_{2} \mathrm{MoO}_{4} \cdot 2 \mathrm{H}_{2} \mathrm{O} 0.01 \mathrm{~g} / \mathrm{L}\right) 70 \mathrm{~mL}$, $\mathrm{pH}$ is 4.8 , distilled water $1 \mathrm{~L}, 40 \mathrm{~min}$ sterilization in $121^{\circ} \mathrm{C}$.

\section{Inoculation}

Grow in the slope of Pleurotus ostreatus by the incubator $25{ }^{\circ} \mathrm{C}$ activation after 3 days, from cant inoculation on the tablet containing solid medium, $\mathrm{N}$ days Pleurotus ostreatus with the tablet, with $10 \mathrm{~mm}$ diameter sterile puncher, inoculation three pieces to $250 \mathrm{~m} 1$ triangle bottle which containing the above liquid medium $100 \mathrm{ml}$, in the $130 \mathrm{r} / \mathrm{min}, 25{ }^{\circ} \mathrm{C}$ under the conditions of shaking table, timing sampling determination of biomass and laccase enzyme activity.

\section{THE ENZYME ACTIVITY DETERMINATION}

Using ABTS Lac oxidation, visible, ultraviolet spectrophotometer is used to test $420 \mathrm{~nm}$ absorbance value within 0 to $3 \mathrm{~min}$, along with the change of time and that the enzyme reaction rate, and then calculate the enzyme activity. With such tendency for $0.5 \mathrm{~L}$ ABTS solution volume and liquid enzyme reaction, determination of reaction within the first $3 \mathrm{~min}$ at $420 \mathrm{~nm}$ Light values increase per minute, and make 1 mol, ABTS an enzyme needed for the transformation of quantity to a dynamic unit (U).

or full quotation. When quotation marks are used, instead of a bold or italic typeface, to highlight a word or phrase, punctuation should appear outside

\section{PleUROTUS OSTREATUS LACCASE ENZYME} ACTIVITY AND GROWTH

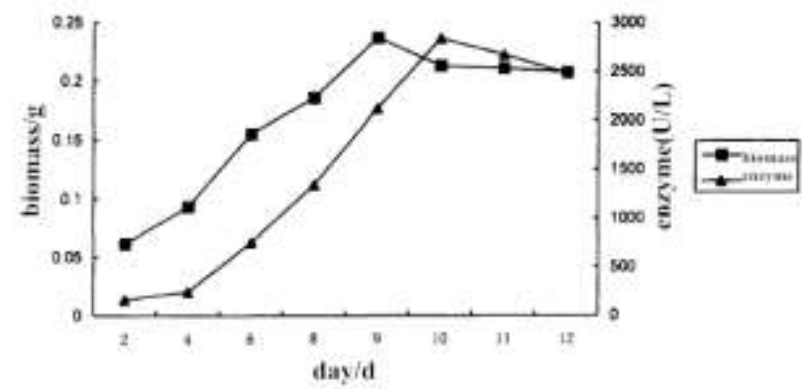

Figure 1. The relationship between Pleurotus ostreatus'growth and laccase enzyme

It can be seen from the figure1,Pleurotus ostreatus producing laccase curve is different to the growth curve, from the curve of laccase production, we can see produce the peak of enzyme activity appeared in the seventh day, and it can be seen from the growth curve, biomass peak appeared in the ninth day, the strains producing enzyme activity and growth correlation, not at the beginning of the cultivation, enzyme activity and growth appear certain correlation, but with the extension of time, there is no correlation between both.

\section{TEMPERATURE ON THE PLEUROTUS OSTREATUS INFLUENCE}

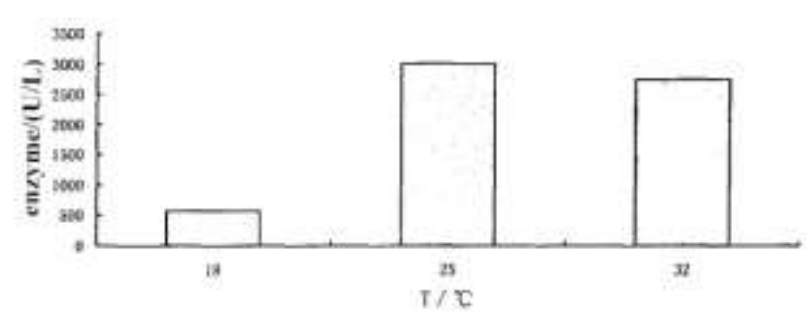

Figure 2. The optimal temperature of laccase enzyme activity

In terms of white rot fungus, can grow in a certain temperature range, but only under the suitable for its temperature, white-rot fungus can secrete laccase in large quantities. Therefore, this research adopts the optimized liquid medium, under the condition of the rotating speed of $130 \mathrm{r} / \mathrm{min}$, examines the different temperature of Pleurotus ostreatus secrete laccase. By the graph, you can see that under the condition of $25{ }^{\circ} \mathrm{C}$ to cultivate Pleurotus ostreatus laccase enzyme activity is highest. Cultivation under temperature $18{ }^{\circ} \mathrm{C}$, the lowest enzyme activity, enzyme activity is only $578.36 \mathrm{U} / \mathrm{L}$, this strain is not too visible adapt to secrete laccase at low temperatures, at high temperatures to secrete laccase is more, but the strains or appropriate secrete laccase in large quantity under the condition of natural room temperature, the temperature too high or too low enzyme activity is not so good. 


\section{RPM OF THE PLEUROTUS OSTREATUS INFLUENCE}

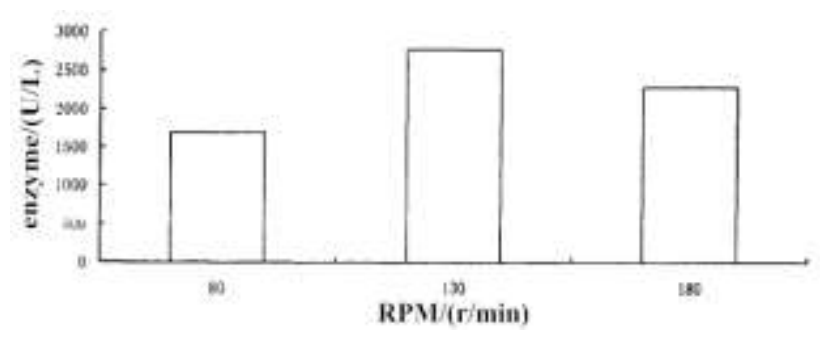

Figure 3. The optimal RPM of laccase enzyme activity

White rot fungus is aerobic microorganisms, cultivating mode of white rot fungus producing laccase influence is more important, shaking table culture increased the efficiency of oxygen transfer and mass transfer, thereby enabling the growth and enzyme production.

Optimize the liquid medium, under the condition of $25{ }^{\circ} \mathrm{C}$, examines the different temperature of Pleurotus ostreatus secrete laccase and the effect of the figure can be seen that the speed of $130 \mathrm{r} / \mathrm{min}$ under the conditions of Pleurotus ostreatus produced enzyme activity, the highest speed too fast or too slow to produce enzyme activity is relatively small, which is associated with the mass transfer of transport oxygen and nutrients, white rot fungus, oxygen is an important factor, to improve the effect of oxygen transportation and mass transfer table is often used to develop, but the mechanical shear force produced by shaking will destroy the structure and activity of the enzyme, adding surfactant effectively protect the activity of laccase. Most of white-rot fungus in table culture conditions for enzyme production, there is also a part of white-rot fungus in static culture conditions for enzyme production.

\section{CONCLUSION}

(1)Choose the optimized culture medium, partial swelling of bolt bacteria produce laccase culture experiments, the results show that when the temperature is $25^{\circ} \mathrm{C}$ when producing laccase enzyme activity, the highest temperature too low enzyme activity is low. Under the condition of the cultivation of the rotating speed of $130 \mathrm{r} / \mathrm{min}$, Pleurotus ostreatus laccase production the highest enzyme activity, speed too high or too low are detrimental to produce enzyme activity.

(2)Optimize the culture medium and the best training environment, partial swollen proposed bolt bacteria in $25{ }^{\circ} \mathrm{C}, 130 \mathrm{r} / \mathrm{min}$ under the conditions of cultivation, selection of optimization of culture medium, the growth curve and the curve of laccase enzyme activity are not synchronized, which don't appear on the same day.

\section{ACKNOWLEDGMENT}

The present work is supported by "the Fundamental Research Funds for the Central Universities" (DL09DB04), the New Century Excellent Talents in University (NCET-10-0277), Province science and technology in the Heilongjiang offends pass item (GC09A403), the Junior Innovation Team.This work is partly performed under the Scientific and Projects of Department of Transportation (201310225084).

\section{REFERENCES}

[1]Jiang Xiaoyun, Ceng Guangming,Huang Danlian,etc. Vaccination white-rot fungus compost repair pentachlorophenol pollution soil [J]. Journal of environmental science, 2006, 27 (12) 2553-2557

[2] Moldes D, Couto S R, Cameselle C, etal. The Study of the degradation of dyes by $\mathrm{MnP}$ of Phanerochaete chrysosporium produced in a fixed - bed bioreactor $[\mathrm{J}]$. Chemosphere, ploidy of 2003 (4) : 295-303 